\title{
Phylogenetic study of endophytic fungi associated with Centella asiatica from Bengkulu and Malaysian accessions based on the ITS rDNA sequence
}

\author{
NANI RADIASTUTI ${ }^{1, \vartheta}$, HUSHSHILA A. BAHALWAN ${ }^{1, v \vee}$, DWI NINGSIH SUSILOWATI, \\ ${ }^{1}$ Department of Biology Faculty of Science and Technology, UIN Syarif Hidayatullah Jakarta. J1. Ir. H. Djuanda no: 90, Ciputat, Banten. Indonesia. \\ "email: nani.radiastuti@uinjkt.ac.id, ${ }^{\text {}}$ hushshila16@gmail.com \\ ${ }^{2}$ Indonesian Center for Agricultural Biotechnology and Genetic Resouces Research and Development, West Java, Indonesia. \\ vrvemail: d_nengsusi@yahoo.com
}

Manuscript received: 2 February 2019. Revision accepted: 6 April 2019

\begin{abstract}
Radiastuti N, Bahalwan HA, Susilowati DN. 2019. Phylogenetic study of endophytic fungi associated with Centella asiatica from Bengkulu and Malaysian accessions based on the ITS rDNA sequence. Biodiversitas 20: 1248-1258. Centella asiatica is one of the medicinal plants which is known to be symbiotic with various endophytic fungi. The purpose of this research was to determine diversity of culturable fungal endophyte from $C$. asiatica. Identification was conducted using molecular phylogenetic analysis based on the ITS rDNA sequence. The result showed that obtained 145 isolates endophytic fungi (from stolons, leaves, roots, petioles) were grouped into 18 morphotaxa (Bengkulu) and 23 morphotaxa (Malaysian). The fungal endophytic were identified as Aspergillus austroafricanus, Aspergillus oryzae, Acrocalymma vagum, Ceratobasidium cornigerum, Ceratobasidium sp., Chaetomium globosum, Colletotrichum karstii, C. gigasporium, C. tabaci, Colletotrichum siamense, Eutypella sp., Fusarium solani, F. oxysporum, F. falciforme, F. keratoplasticum, F. striatum, Fusarium sp., Penicillium capsulatum, Phoma multirostrata, Perenniporia tephropora, Perenniporia sp., Phanerochaete chrysosporium, Phanerochaete stereoides, Phyllosticta capitalensis, Phomopsis asparagi, Peroneutypa scoparia, Phialemoniopsis sp., Mycochaetophora gentinae, Talaromyces sp., Earliella scabrosa, and Trichaptum sp. based on molecular phylogenetic analysis. Fusarium (Nectriaceae) were the most found of fungal endophytes in both $C$. asiatica Bengkulu and Malaysian accession. The majority strain are including Ascomycetes and Basidiomycetes. The identification of endophytic fungi from medicinal plants is needed as a preliminary study to determine the potential of endophytic fungi producing bioactive compounds.
\end{abstract}

Keywords: Centella asiatica, endophytic fungi, phylogenetic tree

\section{INTRODUCTION}

Centella asiatica (L.) Urb. (Apiaceae) (English: centella or Asiatic pennywort, Indonesia: pegagan) is an important medicinal plant in Indonesia and Southeast Asia. This plant is distributed in Indian subcontinent, Southeast Asia, East Asia, West Asia (Saudi Arabia and Yemen), Africa, and Australia (Gupta 2013). This species is frequently found in grassland (along riversides) and in cultivated lands (Cook 1996), as well as in ponds and streamsides, evergreen forests, fields, garden, and flooded agricultural fields. The centella extract has been widely known to cure various diseases, such as skin disorders, gastric ulcers, asthma, hemorrhoids, dysentery and tuberculosis (Zahara et al. 2014; Radji et al. 2015). Several studies noted that medicinal properties of medicinal plants are related to the endophytic microbes, especially endophytic fungi, reside within the medicinal plants (Jia et al. 2016; Kaur et al. 2014).

Endophytic fungi live inter- or intracellularly in the plant without causing symptoms of the disease under normal circumstances (Hyde and Soytong 2008; Delaye et al. 2013). Some endophytic fungi have specific relationships with host plants that can significantly affect the production of medicinal compounds from their host (Jia et al. 2016). For example, an endophytic fungus Penicillium sp. from $C$. asiatica produced a high antioxidant activity, similar to its host, with IC50 value $54.72 \pm 2.19 \mu \mathrm{g} / \mathrm{mL}$ (Devi and Prabakan 2014). Similar results were also reported from the study of the endophytic fungi from cinchona, where the endophytic fungi produced similar compound with their hosts (Radiastuti et al. 2015; Hidayat et al. 2016)

Studies on the endophytic fungi from $C$. asiatica have mainly been focused on the diversity and analysis of the phytochemical contents (Joshi and Chaturvedi 2013; Devi and Prabakaran 2014; Nalini et al. 2014; Lulasto 2015). A previous diversity study of the endophytic fungi from $C$. asiatica was based on the morphological data which is not suitable to reveal the true diversity of the endophytic fungal community associated with $C$. asiatica. A study on the endophytic fungal diversity of $C$. asiatica using molecular analysis was only conducted on the leaves part (Rakotoniriana et al. 2008). A few species of the endophytic fungi associated with $\mathrm{C}$. asiatica was reported Indonesia, such as Colletotrichum spp., Fusarium spp., and Phoma spp. (Hasyyati et al. 2017). Therefore, it is necessary to conduct molecular analysis of the diversity of fungal endophytes associated with various organs of $C$. asiatica to reveal more accurate data on the diversity of these fungal group. This study was conducted to determine the diversity of endophytic fungi of $C$. asiatica (Bengkulu and Malaysian accession in Indonesia) by using ITS rDNA sequences. 


\section{MATERIALS AND METHODS}

\section{Fungal sources and morphotyping}

A total of 145 endophytic fungal cultures isolated from various organs of $C$. asiatica were obtained from Biogen Culture Collection (Biogen CC) at Indonesian Center for Agricultural Biotechnology and Genetic Resouces Research and Development (ICABIOGRAD), Bogor, Indonesia. Of them, 85 and 60 cultures were isolated from Malaysian and Bengkulu accessions, respectively. The fungal isolates from the Malaysian accession composed of 24 isolates from leaves, 17 isolates from roots, 11 isolates from petioles, and 33 isolates obtained from the stolon. While from Bengkulu accession composed of 11 isolates from the leaves, 20 isolates from the roots, 6 isolates from the petioles, and 23 isolates from the stolons. The fungal isolates from Malaysian and Bengkulu accessions belong to 23 and 18 morphotypes, respectively. These morphotypes were subjected for further molecular analysis.

\section{Isolation and extraction of DNA}

The isolation and extraction of DNA of the fungal endophytes were conducted according to the protocol described by Hidayat et al. 2016.

\section{DNA amplification and sequencing}

The DNA amplification was performed by Polymerase Chain Reaction (PCR) method in a $25 \mu \mathrm{L}$ reaction mixture consisting of nuclease-free water $8.5 \mu \mathrm{L}$, Go Taq green master mix $12.5 \mu \mathrm{L}, 1 \mu \mathrm{L}$ primer ITS5 (forward) $5^{\text {ee }}$ TCCTCCGCTTATTGATATGC- $3^{\circ}$ ) and ITS4 (reverse) (5'-TCCGTAGGTGAACCTGCGC-3') (White et al. 1990), and $2 \mu \mathrm{L}$ of DNA template. The PCR conditions used in this study were set as follows: 5 minutes at $94^{\circ} \mathrm{C}$ for initial denaturation, followed by 35 cycles of 30 seconds at $94^{\circ} \mathrm{C}$ for denaturation, 30 seconds at $52^{\circ} \mathrm{C}$ for annealing process, 30 seconds at $72^{\circ} \mathrm{C}$ for extension and 7 minutes at $72^{\circ} \mathrm{C}$ for the final extension. The product of PCR amplification was electrophoresed in a $1.5 \%(\mathrm{w} / \mathrm{v})$ agarose gel amended with $1 \%$ red gel and was immersed in $1 \mathrm{x}$ TAE buffer. The electrophoresis condition was set at $110 \mathrm{~V}$ for $30 \mathrm{~min}$. A 1 $\mu$ Lof DNA marker (1000 bp) was used in the gel. DNA visualization was conducted by Gel Doc ${ }^{\mathrm{TM}}$ XR (BioRad, USA). The PCR products were sent to First Base (Malaysia) for sequencing.

\section{Phylogenetic analysis}

The phylogenetic analysis was performed using the Maximum Parsimony (MP) method in the PAUP 4.0.b10 program (Swofford 2002). The heuristic method using tree bisection reconstruction (TBR) with the addition of 1000 random sequence algorithms was performed to obtain the optimal tree. The Tree Length (TL), Consistency Index (CI), Retention Index (RI), Related Consistency Index (RC), and Homoplasy Index (HI) were calculated. Internal branch strength of the phylogenetic tree in MP analysis was tested by Bootstrap (BS) analysis using 1000 replications. Bootstrap (BS) value > 50\% was displayed on the phylogenetic tree.

\section{RESULTS AND DISCUSSION}

\section{Phylogenetic analyses \\ Malaysian accession}

A dataset generated from the phylogenetic analysis of Malaysian accession contains 125 sequences including Rhizopus oryzae CBS 11207 (NR103595) and Rhizopus oryzae strain 783018 (GU594768). This dataset composed of 891 total characters, which included 222 constant characters, 89 uninformative characters, and 580 informative characters $(\mathrm{CI}=0.404, \mathrm{RI}=0.760, \mathrm{RC}=$ $0.347, \mathrm{HI}=0.596)$. The phylogenetic tree showed that four sequences of the fungal endophytes belong to Basidiomycota, and 19 sequences belong to Ascomycota (Fig. 1). All of four Basidiomycota sequences (MM1, MM6, MM12, and MM21) belong to Agaricomycetes. The MM1 sequence nested in the clade containing unidentified Ceratobasidium sp. strain R113 and Ceratobasidium sp. strain AG A with a high BS (86\%). These isolates also formed a sister clade with $C$. ramicola strain CBS 758.79 with a $100 \%$ BS. These results showed that MM1 belong to Ceratobasidium sp. The MM6 sequence was determined as Earliella scabrosa. due to nesting with unidentified $E$. scabrosa strain BRFM 1106 with a high BS (100\%). The MM21 sequence was determined as Perenniporia sp. due to form a sister clade with $P$. corticola strain SKB1 and SK13, P. tephroppora strain D2 with a $100 \%$ BS. While MM12 sequence was determined as Phanerochaete stereoides due to a monophyletic with $P$. stereoides strain VPCI 207312 with $60 \%$ BS.

In the Ascomycota clade, MM7 sequence nested in the Guignardia clade and formed a monophyletic clade with $G$. mangiferae strain CBS 101228 and its asexual state Phyllosticta capitalensis strain CBS 117118 with $100 \%$ BS. Therefore, this sequence was determined as $P$. capitalensis (Phyllosticta is an accepted name in this group). The MM13, MM15, and MM16 sequences nested in the Eurotiomycetes clades. The isolates MM13 can only be determined as Aspergillus oryzae due to nesting in the same clade with several sequences of Aspergillus species such as A. oryzae strain CBS 466 91, A. oryzae type strain NRRL 447, A. flavus type strain ATCC 16883 (52\% BS). The isolates MM15 was determined as Penicillum capsulatum due to formed a monophyletic with the $P$. capsulatum strain species CBS 27458 and the strain type NRRL 2056 (71\%) in the Penicillium clade. While MM16 sequence was determined as Talaromyces sp. because did not form a monophyletic clade with any Talaromyces species in the Talaromyces clade.

The Sordariomycetes clade consisted of six subclades (Fig. 1). In the first subclade, MM2 was determined as Colletotrichum karstii due to form a monophyletic clade with C. karstii strain CPC 26233 and type strain CBS 132134 (75\% BS). The MM9 sequence formed a monophyletic with $C$. siamense strain PHL12 and CBS 112985 strain (93\% BS), while MM18 and MM23 sequences formed a closely related to $C$. tabaci type strain CPC 18945 and strain N150 with a 76\% BS. The identity of MM9 formed a monophyletic with Colletotrichum siamense strain PPHL12 with 93\%BS. In addition, MM14 
sequence was determined as $C$. gigasporum due to form a monophyletic group with $C$. gigasporum strain CBS 125730 and CBS strain 101881 with a high level of bootstrap support $(100 \%)$. In the second subclade, MM3 and MM17 sequences formed a monophyletic with Fusarium solani strain GA12 and strain CPC 27200 with 95\% bootstrap value. Therefore, the MM3 and MM17 sequences were identified as $F$. solani and MM20 formed a monophyletic with $69 \%$ BS. However, MM4 and MM22 sequences were tentatively determined as Fusarium sp. because did not form a monophyletic clade with a single representative Fusarium sequences in this subclade. In the third subclade, MM19 sequence was identified as Chaetomium globosum due to nesting in the monophyletic clade with $C$. globosum strain ATCC 6250 and type strain CBS $16062(100 \%$ BS). In the fourth subclade, MM11 sequence was determined as Phomopsis asparagi as this sequence formed a monophyletic clade with $P$. asparagi strain HL57 and B144 with a high BS (70\%). Sequence of MM8 was determined as Phialemoniopsis due to form a clade with $P$. hongkongensis strain FMR 6321 and HKU39, $P$. curvata strain UTHSC 04956 (86\%). The MM5 sequence was also tentatively determined as Etypella sp. due to form a monophyletic with Etypella sp. MEF14 (100\% BS), while MM10 sequence was identified as Peroneutypa scoparia because this sequence formed a monophyletic clade with P. scoparia MFLUCC 110615 $(89 \%)$.

\section{Bengkulu accession}

The MP analysis of endophytic fungal sequences from Bengkulu accession comprised of 120 sequences with 925 total characters of which 278 characters were constant, 94 characters was uninformative, and 553 informative characters $(\mathrm{CI}=0.397, \mathrm{RI}=0.857, \mathrm{RC}=0.349, \mathrm{HI}=$ 0.603 ). The phylogenetic tree showed that members of the fungal sequences from Bengkulu accession divided into Basidiomycota clade (4 sequences) and Ascomycota cade (14 sequences) (Fig. 2). All of the sequences in the Basidiomycota clade belong to Agaricomycetes, while members of the Ascomycota clade consisted of Sordariomycetes (11 sequences), Eurotiomycetes (1 sequence), Dothideomycetes (2 sequences) (Fig. 2). In the Agaricomycetes clade, MB2 sequence was determined as Phanerochaete chrysosporium due to nesting in the same clade with $P$. chrysosporium strain $\mathrm{H} 008$ with a high BS $(100 \%)$, and this clade is sister clade with $P$. chrycocporium HHB type strain 6251 . The sequence of MB11 was tentatively identified as Trichaptum sp. because this sequence formed a monophyletic with unidentified Trichaptum sp. E7082 strain and Trichaptum sp. E7083 strain $(83 \%$ BS). The species identity of MB5 sequence was determined as Perenniporia tephropora as this sequence nested in the same clade with $P$. tephropora species strains A1S3 D98 and P. tephropora strains Cui 9029 with a low BS. While MB20 sequence was determined as Ceratobasidium comigerum because it formed a monophyletic clade with $C$. cornigerum strain XSD $(100 \%$ BS $)$
In the Ascomycota clade, the MB19 and MB21 sequences were determined as Mycochaetophora gentianae as these sequences formed a sister clade with M. gentianae MAFF 241068 and type strain MAF239231, while MB3, MB9, and MB17 sequences belong to Fusarium oxysporum due to nesting in the same clade with $F$. oxysporum strains CBS 129.24, F. oxysporum strain CPC 27701 and $F$. oxysporum strains CSB F338 with a high bootstrap value (100\%). The endophytic fungal sequences of MB7, MB8, and MB10 were determined as $F$. falciforme as these sequences formed a monophyletic clade with $F$. falciforme strains CBS 475.67 and $F$. falciforme strains CBS 132313 with a high BS (74\%). The MB12 sequence was determined as $F$. keratoplasticum due to nesting in the same clade with three sequences of $F$. keratoplasticum, viz, $F$. keratoplasticum IHEM 19026 MITS 1840, F. keratoplasticum type strain FRC S 2477, and $F$. keratoplasticum strains CBS 139461 with $70 \%$ BS. In the Colletotrichum clade, the MB14 and MB18 sequences were determined as Colletotrichum tabaci as both sequences formed a monophyletic clade with $C$. tabaci type strain CPC 18945 and C. tabaci N150 strains with low BS. In the Eurotiomycetes clade, the MB1 sequence was determined as Aspergillus austroafricanus due to this sequence formed a monophyletic clade with $A$. austroafricanus type strain NRRL 233 with low BS. In the Dothideomycetes clade, the MB4 sequence was determined as Acrocalymma vagum as this sequence formed a monophyletic clade with $A$. vagum strain CPC 24222 (100\% BS), while the MB16 sequence was determined as Phoma multirostrata because this sequence formed a monophyletic clade with three sequences of $P$. multirostrata with a high bootstrap support $(90 \%)$.

\section{Discussion}

This study found that the highest number of endophytic fungi was mostly obtained from stolons, followed by leaves, roots, petioles from $C$. asiatica of Malaysian accession (table 1), and from $C$. asiatica of Bengkulu accession followed roots, leaves, and petioles (table 2).

The distribution of endophytic fungi occurs in different host plants and organs of a host plant. Table 1 and Table 2 shows the distribution of the endophytic fungi in the $C$. asiatica plant of Malaysian and Bengkulu accession. The number of endophytic fungi obtained from the stolons was the largest number compared to the number obtained from the other organs. The distribution of endophytic fungi in the host plants can be influenced by several factors, such as the origin of the colonized endophytes and the substances in the plant organ tissues. The distribution of endophytic fungi is possibly related to the ability of each endophytic species to use specific substrates or plant tissues in showing the distribution strategy to obtain resources from the same plants (Jia et al. 2016). Arnold and Lutzoni (2007) suggested that different endophytic composition in different host organs occurred due to the histologic differences and the availability of the plant organ nutrients, in which endophytic fungi colonized. Arnold et al. (2003) stated that different leaves in the same tree may have distinct endophytic colonies. 

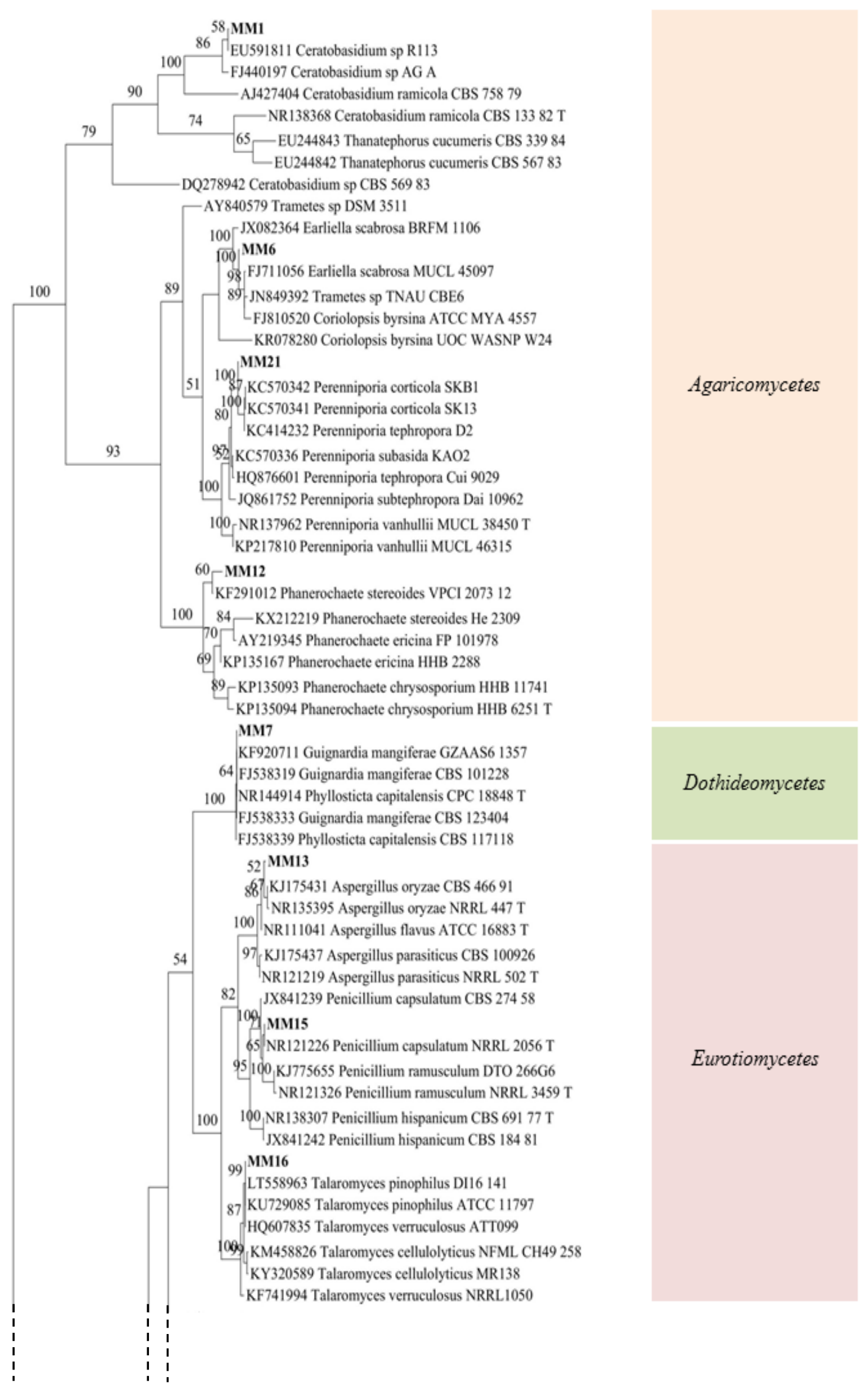

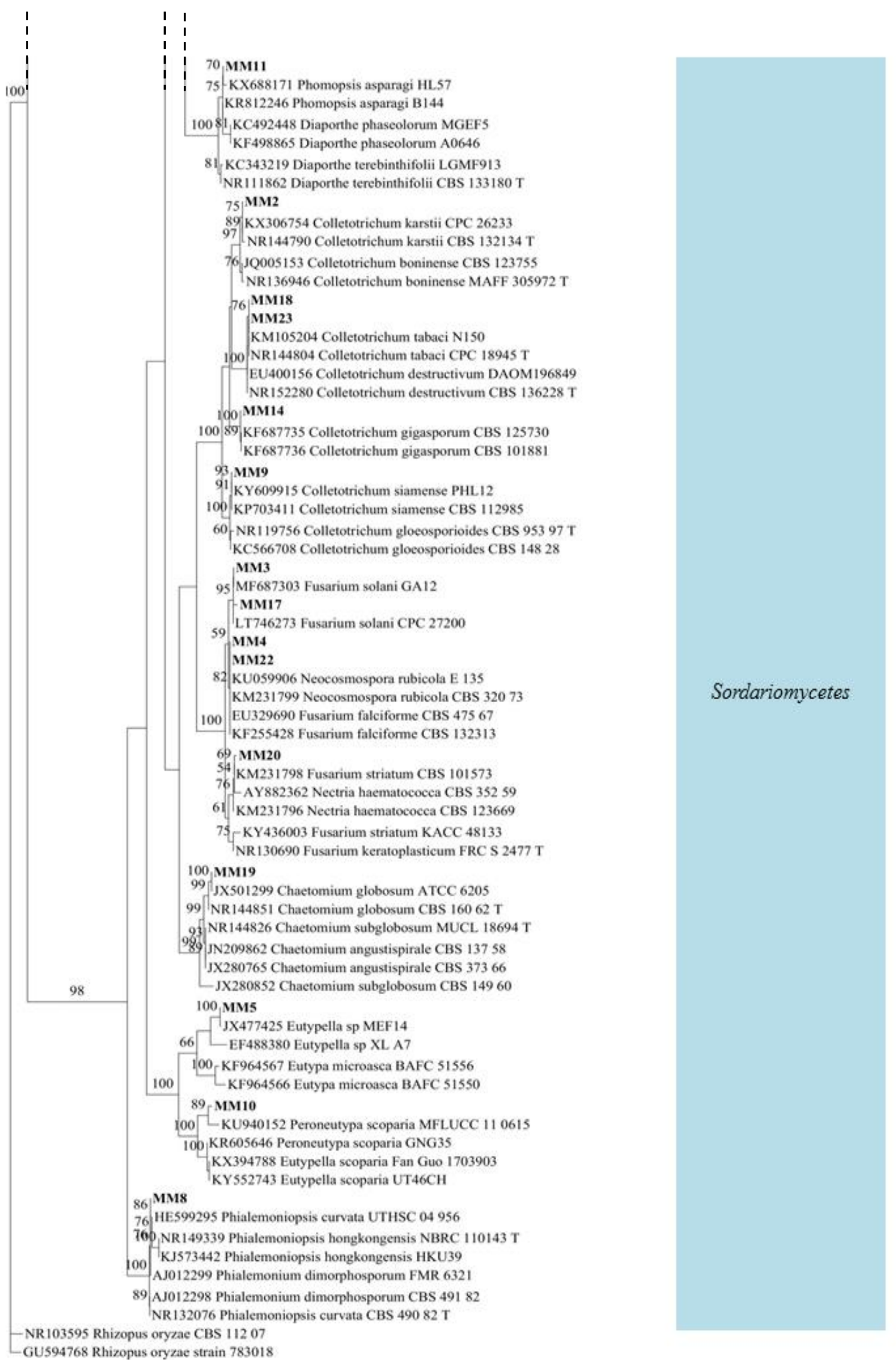

Figure 1. MP tree generated from the ITS rDNA sequences from endophytic fungal isolate morphotypes from $C$. asiatica (Malaysian accession) and related sequences 

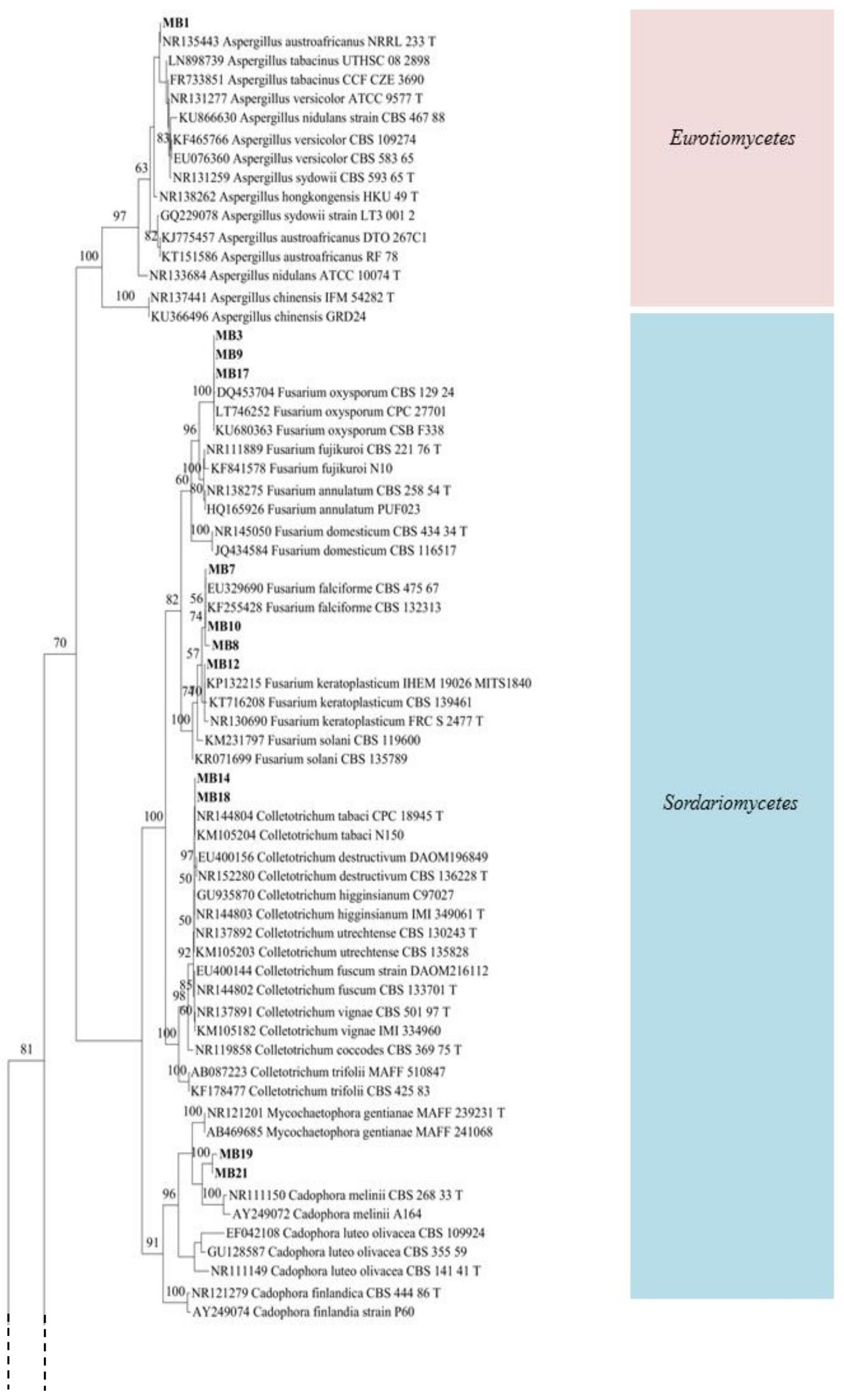


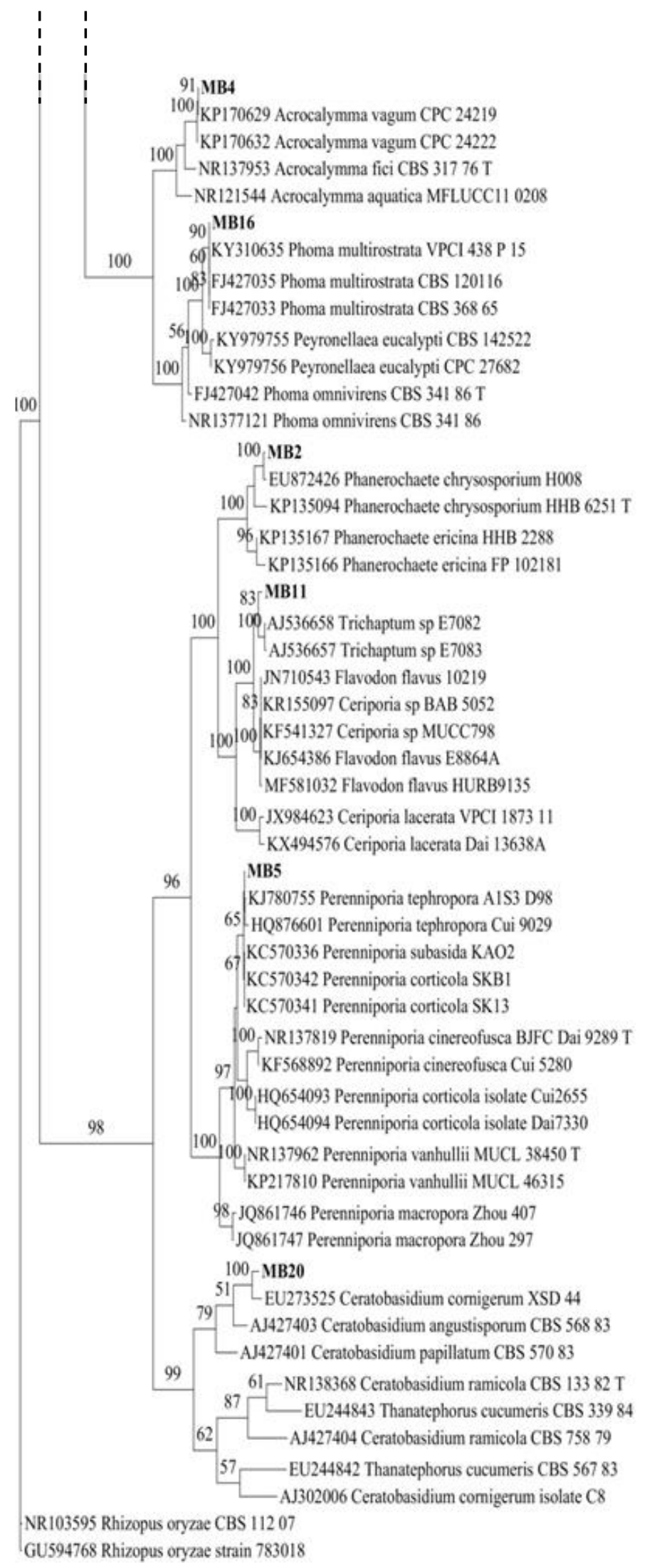

Dothideomycetes

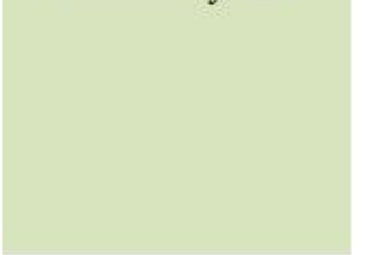

Agaricomycetes

Figure 2. MP tree generated from the ITS rDNA sequences of the endophytic fungi from $C$. asiatica (Bengkulu accession) and related sequences 
Table 1. Fungal endophytic species distribution in the different organs of $C$. asiatica of Malaysian accession

\begin{tabular}{|c|c|c|c|c|}
\hline Taxa & Leaves & Roots & Petioles & Stolons \\
\hline \multicolumn{5}{|l|}{ Sordariomycetes } \\
\hline Colletotrichum kartsii & 1 & - & - & - \\
\hline C. tabaci 1 & 1 & - & - & - \\
\hline C. tabaci 2 & - & 4 & 3 & - \\
\hline C. gigasporum & 3 & - & - & - \\
\hline C. siamense & 10 & - & - & - \\
\hline Fusarium solani 1 & 1 & - & - & 6 \\
\hline$F$. solani 2 & - & - & - & 6 \\
\hline F. striatum & - & - & - & 2 \\
\hline Fusarium sp. 2 & - & - & - & 1 \\
\hline Fusarium sp. 3 & - & - & 1 & - \\
\hline Chaetomium globosum & - & 1 & - & - \\
\hline Phomopsis asparagi & 1 & 1 & - & - \\
\hline Phialemoniopsis sp. & - & 4 & - & - \\
\hline Eutypella sp. & - & 1 & - & - \\
\hline Peroneutypa scoparia & - & 1 & - & - \\
\hline \multicolumn{5}{|l|}{ Agariomycetes } \\
\hline Ceratiobasidium sp. & - & 3 & - & 9 \\
\hline Perenniporia scoparia & 4 & - & - & - \\
\hline Phanerochaete steroides & 1 & - & - & - \\
\hline Earliella scabrosa & - & - & 3 & - \\
\hline \multicolumn{5}{|l|}{ Dothidiomycetes } \\
\hline Phyllosticta capitalensis & - & - & 4 & - \\
\hline \multicolumn{5}{|l|}{ Eurotiomycetes } \\
\hline Aspergillus oryzae & - & 2 & - & - \\
\hline Penicillium capsulatum & 2 & - & - & - \\
\hline Talaromyces sp. & - & - & - & 2 \\
\hline Total & 24 & 17 & 11 & 26 \\
\hline
\end{tabular}

This study also showed that endophytic fungal community in both Malaysian and Bengkulu accession is dominated by Sordariomycetes taxa (Table 1 and Table 2). Members of Sordariomycetes occupy about $66 \%$ and $61 \%$ of the endophytic fungal community in Malaysian and Bengkulu accessions, respectively. The phylogenetic tree showed that the tree form four clades of polyphyletic clusters and were divided into 4 classes, namely Eurotiomycetes (13\%), Sordariomycetes (66\%), Dothideomycetes (4\%), and Agaricomycete (17\%) from C. asiatica of Malaysian accession (Table 1) and fungal endophyte from $C$. asiatica of Bengkulu accession showed that Sordariomycetes (61\%), Dothideomycetes (11\%) and Eurotiomycetes (6\%) classes (Table 2).

Almost all of the total endophytic fungi species found in $C$. asiatica plants in Bengkulu accession are different from those of Malaysian accession. The endophytic fungi of $C$. asiatica of Bengkulu accession could be identified as Aspergillus austroafricanus, Acrocalymma vagum, Ceratobasidium cornigerum, Colletotrichum tabaci, Fusarium oxysporum, F. falciforme, F. keratoplasticum, Phoma multirostrata, Perenniporia tephropora, Phanerochaete chrysosporium, Mycochaetophora gentinae, and Trichaptum sp. The endophytic fungi of $C$. asiatica of Malaysian accession could be identified as Aspergillus oryzae, Ceratobasidium sp., Chaetomium globosum, Colletotrichum karstii, C. gigasporium, C. tabaci, Colletotrichum siamense, Eutypella sp., Fusarium
Table 2. Fungal endophytic species distribution in the different organs of $C$. asiatica of Bengkulu accession

\begin{tabular}{|c|c|c|c|c|}
\hline Taxa & Leaves & Roots & Petioles & Stolons \\
\hline \multicolumn{5}{|l|}{ Sordariomycetes } \\
\hline Colletotrichum tabaci 1 & 2 & - & - & - \\
\hline C. tabaci 2 & 2 & - & 2 & 2 \\
\hline Fusarium oxysporum 1 & - & 1 & - & - \\
\hline F. oxysporum 2 & - & 2 & - & 6 \\
\hline F. oxysporum 3 & - & 1 & - & 1 \\
\hline F. falciforme 1 & - & 2 & - & 2 \\
\hline F. falciforme 2 & - & 6 & - & 3 \\
\hline F. falciforme 3 & 1 & 1 & - & 1 \\
\hline F. keratoplasticum & - & 1 & - & 2 \\
\hline Mycochetopthora gentinae 1 & 2 & - & - & - \\
\hline Mycochetopthora gentinae 2 & 1 & - & - & - \\
\hline \multicolumn{5}{|l|}{ Agaricomycete } \\
\hline Ceratiobasidium cornigerum & - & 1 & - & 9 \\
\hline Phanerochaete chrysosporium & - & - & 2 & - \\
\hline Perenniporia tephropora & 1 & - & - & - \\
\hline Trichaptum sp. & - & - & - & 1 \\
\hline \multicolumn{5}{|l|}{ Dothidiomycetes } \\
\hline Acrocalymma vagum & 1 & 2 & - & - \\
\hline Phoma multirostrata & 1 & 3 & - & 3 \\
\hline \multicolumn{5}{|l|}{ Eurotiomycetes } \\
\hline Aspergillus austroafricanus & 1 & & 2 & - \\
\hline Total & 12 & 20 & 6 & 30 \\
\hline
\end{tabular}

solani, F. striatum, Fusarium sp., Penicillium capsulatum, Phyllosticta capitalensis, Perenniporia sp, Peroneutypa scoparia, Phanerochaete steroides, Phomopsis asparagi, Phialemoniopsis sp., Talaromyces sp. and Earliella scabrosa. Based on the genus level, endophytic fungi were identified in both accessions of Pegagan plants, namely Aspergillus, Ceratobasidium, Colletotrichum, Fusarium, Perenniporia, and Phanerochaete, but on the species level wasn't same between endophytic fungi from $C$. asiatica Malaysian and Bengkulu accession. Therefore, the species found in each Pegagan plant are endophytic fungi specific to each plant.

The most dominant genus of endophytic fungi from $C$. asiatica are Colletotrichum (4 species) and Fusarium (5 species), because these two genera have capability to be distributed in some organs of plant. This result is in agreement with Arnold and Lutzoni (2007) who noted that the endophytic fungi that are often isolated from tropical plants are Colletotrichum and Fusarium. Both taxa were also found in Manoko and Boyolali accessions of $C$. asiatica (Hasyyati et al. 2017) as well as in Indian accession (Gupta and Chaturvedi 2017). Beside Colletotrichum and Fusarium, in this study found some genera such as Guignardia, Phoma, Phomopsis, Penicillium and some of these genera were also found in the same research such as by Ginting (2013) has isolated endophytic fungi from the leaves of $C$. asiatica of Malaysian accession and obtained three species of 
Mycoleptodiscus indicus, Glomerella cingulata (teleomorph of Colletotrichum gloeosporioides), and Stagonosporopsis cucurbitacearum. Devi and Prabakan (2014) found Penicillium sp. of local C. asiatica from India. Rakotoniriana et al. (2008) have also identified some genera, such as Guignardia, Phoma, Phomopsis, Leptosphaerulina, and Phialophora from C. asiatica, from Mangoro and Madagascar.

Another common fungal endophytes are Phyllosticta (sexual state: Guignardia), Phyllosticta can be found in the $C$. asiatica as an endophyte, or saprophyte or pathogenic in the other plant. The $G$. mangiferae ( $P$. capitalensis), a ubiquitous endophyte of woody plants and as pathogen some genus plant e.i Citrus, Mangifera, Vitex, Artocarpus, Musa, Psidium, and Orchid. G. mangiferae is the same species as G. endophyllicola (anamorf: Phyllosticta modalensis), based on molecular identification with encoding ITS2 (Baayen et al. 2002). However, subsequent research by Glienke et al. (2011) revealed that $P$. capitalensis has low based sequence homology with referenced isolates, G. mangiferae. Hence, it is a strong statement that these two species are distinct species.
Many endophytic fungal isolates from $C$. asiatica are unidentified until species level based on the ITS rDNA sequence, therefore, further analysis using additional genes is necessary to determine these taxa until the species level. A number of previous studies had used ITS primer to identify the endophytic fungi, but it proven insufficient for several highly diverse genera. Majority genus Fusarium included as species complex, meanwhile, need some gen for the identification for example research of Herron et al. 2015 described eight more species in the fujikuroi complex from stem cancers and branches of Pinus plants. According to research of Watanabe et al. 2011, currently, the identification of Fusarium involving combination of several gene regions such as the internal transcribed spacer (ITS) and the elongation factor $1 \alpha(\mathrm{EF}-1 \alpha), \beta$-tubulin $(\beta$ tub) and aminoadipate reductase (lys2) gene regions. $A$. austroafricanus is a new species found, based on phylogenetic with multilocus analysis by Jurjevic et al. (2012) as a part of the Aspergillus Versicolores group with closed relatives, namely $A$. versicolor, A. tabacinus, $A$. fructus, A. protuberus, and A. amoneus (Table 2).

Table 2. Additional gene regions for the identification of genera found in this study

\begin{tabular}{|c|c|c|}
\hline Genera & Genes/Regions & References \\
\hline Aspergillus & $\begin{array}{l}\beta \text {-tubulin gene (BT2), calmodulin gene (CF), ITS and partial lsu-rDNA (ID), RNA } \\
\text { polymerase } 2 \text { gene (RPB2), }\end{array}$ & Jurjevic et al. (2012) \\
\hline Acrocalymma & ITS regions and LSU gene sequences & Jayasirri et al. (2019) \\
\hline Acremonium & ITS regions, NL209, NL912, tubulin gene (TUB1F, TUB2R) & Zhang et al. 2017 \\
\hline Colletotrichum & $\begin{array}{l}\text { ITS regions, partial actin gene (ACT), } \beta \text {-tubulin gene (TUB2), calmodulin gene } \\
\text { (CAL), glutamine synthetase, glyceraldehyde-3-phosphate dehydrogenase genes } \\
\text { (GPDH) }\end{array}$ & Prihastuti et al. (2009) \\
\hline Chaetomium & $\begin{array}{l}\text { ITS regions, partial ribosomal large subunits (LSU rDNA), RNA polymerase II gene } \\
\text { (RPB2), } \beta \text {-tubulin gene (TUB) }\end{array}$ & Zhang et al. (2006) \\
\hline Ceratobasidium & $\begin{array}{l}\text { ITS and LSU regions, RNA polymerase II gene (RPB2), Elongation factor } \alpha \text { gene } \\
\text { (EF- } \alpha \text { a), mitochondria gene (ATP6) }\end{array}$ & Gonalez et al. (2016) \\
\hline Eutypella & ITS regions, $\beta$-tubulin gene $(\mathrm{Bt} 2 \mathrm{a}, \mathrm{Bt} 2 \mathrm{~b})$ & Mayorquin et al. (2016) \\
\hline Fusarium & $\begin{array}{l}\text { ITS regions, } \beta \text {-tubulin gene ( } \beta \text {-tub), Elongation factor } \alpha \text { gene (EF- } \alpha \mathrm{a}) \text {, aminoadipate } \\
\text { reductase gene (lys } 2 \text { ) }\end{array}$ & Watanabe et al. (2011) \\
\hline Phyllosticta & $\begin{array}{l}\text { ITS regions, partial translation elongation factor 1-alpha gene (TEF1), actin gene } \\
\text { (ACT), and glyceraldehyde 3-phosphate dehydrogenase (GPDH) gene regions. }\end{array}$ & Su and Cai (2012) \\
\hline Penicillium & ITS regions, BenA, CaM and RPB 2 regions & Wang et al. (2017) \\
\hline Phoma & $\begin{array}{l}\text { ITS-rDNA, tubulin gene ( } \beta \text { TUB), actin gene (ACT), translation elongation factor } 1 \\
\text { alpha gene (tef1), Histone protein gene }\end{array}$ & Rai et al. (2014) \\
\hline Phomopsis & $\begin{array}{l}\text { ITS regions, partial translation elongation factor } 1 \text {-alpha gene (TEF1), } \beta \text { tubulin gene } \\
\text { (TUB), histone H3 gene (HIS), calmodulin gene (CAL) }\end{array}$ & Gomes et al. (2013) \\
\hline Perenniporia & ITS and LSU-rDNA regions & Zhao and Cui (2017) \\
\hline Phanerochaete & ITS regions, nLSU, RNA polymerase II largest subunit (RPB1, RPB2) & $\begin{array}{l}\text { Floudas and Hibbett } \\
(2015)\end{array}$ \\
\hline Phialemonipsis & ITS regions, D1/D2 domains of the $28 \mathrm{~S}$ rRNA, actin gene, $\beta$-tubulin gene & Perdomo et al. (2017) \\
\hline Mycochetopthora & $\begin{array}{l}\text { ITS regions, partial translation elongation factor } 1-\alpha \text { gene (TEF1), RNA polymerase } \\
\text { I, II gene (RPB1, RPB2) }\end{array}$ & Carlson et al. (2014) \\
\hline Talaromyces & $\begin{array}{l}\text { ITS regions, calmodulin gene (CaM), } \beta \text {-tubulin gene (TUB), RNA polymerase II } \\
\text { largest subunit gene (RPB2) }\end{array}$ & Su and Niu (2018) \\
\hline Trichaptum & $\begin{array}{l}\text { ITS regions, IGS1, IGS2, partial translation elongation factor gene (EF1160 F, } \\
\text { EF1750 R) }\end{array}$ & $\begin{array}{l}\text { Kauserud and Schumacher } \\
\text { (2003) }\end{array}$ \\
\hline Earliella & $\begin{array}{l}\text { ITS regions, nLSU, partial translation elongation factor 1-alpha gene (TEF1), RNA } \\
\text { polymerase I, II gene (RPB1, RPB2) }\end{array}$ & Justo and Hibbet, 2011 \\
\hline
\end{tabular}


This study found several genera as new records of endophytic fungi associated with $C$. asiatica of Bengkulu and Malaysian accessions such as Perenniporia, Phanerochaete, Acrocalymma, Mycochaetophora, Chaetomium, Eutypella, Peroneutypa, Phialemoniopsis, Talaromyces, and Earliella. These fungi are also rarely found as endophytes in other host plants.

Several genera of endophytic fungi from the $C$. asiatica plant of Bengkulu accession was not found in Malaysian accessions namely Acrocalymma, Mycochaetophora, and Phoma. In contrast, endophytic fungi genus were identified in Malaysian accession but not found in Bengkulu accession were Chaetomium, Eutypella, Penicillium, Peroneutypa, Phialemoniopsis, Phomopsis, Phyllosticta, Talaromyces, and Trametes. Endophytic fungi are ubiquitous and occur within different plants in various ecosystems. This study provides information on differences of fungal endophytes diversity, community, composition in different tissues of $C$. asiatica.

\section{ACKNOWLEDGEMENTS}

This study was financially supported by the LP2M of State Islamic University of Syarif Hidayatullah, Jakarta, Indonesia. The Integrated Laboratory Center, State Islamic University Syarif Hidayatullah, Jakarta and Indonesian Center for Agricultural Biotechnology and Genetic Resources Research and Development (ICABIOGRAD), Bogor, Indonesia are thanked for supporting research facilities during this study.

\section{REFERENCES}

Arnold AE, Lutzoni F. 2007. Diversity and host range of foliar fungal endophytes . Ecology 88 (3): 541-549. DOI: 10.1890/05-1459.

Arnold AE, Mejia LC. Kyllo D, Rojas EI, Maynard Z, Robbins N, Herre E.A. 2003. Fungal endophytes limit pathogen damage in a tropical tree. Proc Nat Acad Sci USA 100 (26): 15649-15654. DOI: 10.1073/pnas.2533483100.

Carlson A, Justo A, Hibbett DS. 2014. Species delimitation in Trametes: a comparison of ITS, RPB1, RPB2 and TEF1 gene phylogeny. Mycologia 106 (4): 735-745. DOI: $10.3852 / 13-275$

Bacon CW, White JF, Jr (ed). 2000. An overview of endophytic microbes: Endophytism defined. Marcel Dekker, New York.

Baayen RP, Bonants PJM, Verkley G, Carroll GC, Aa HA, Van Der, Weerdt M, De, Azevedo JL. 2002. Nonpathogenic isolates of the citrus black spot fungus, Guignardia citricarpa, identified as a cosmopolitan endophyte of woody plants, G. mangiferae (Phyllosticta capitalensis). Phytopathology 92 (5): 464-477.

Chen XY, Qi YD, Wei JH, Zhang Z, Wang DL, Feng JD, Gan BC. 2011. Molecular identification of endophytic fungi from medicinal plant Huperzia serrata based on rDNA ITS analysis. World J Microbiol Biotechnol 27: 495-503. DOI: 10.1007/s11274-010-0480-x.

Damm U, O'Connell RJ, Groenewald JZ, Crous PW. 2014. The Colletotrichum destructivum species complex - hemibiotrophic pathogens of forage and field crops. Stud Mycol 79 (1): 49-84. DOI: 10.1016/j.simyco.2014.09.003.

Delaye L, García-Guzmán G, Heil M. 2013. Endophytes versus biotrophic and necrotrophic pathogens are fungal lifestyles evolutionarily stable traits? Fungal Div 60 (1): 125-135. DOI: 10.1007/s13225-013-0240y.

Devi NN, Prabakaran JJ, Wahab F. 2012. Phytochemical analysis and enzyme analysis of endophytic fungi from Centella asiatica. Asian Pac J Trop Biomed 2 (3): 1280-1284.
Devi NN, Prabakan JJ. 2014. Bioactive metabolites from an endophytic fungus Penicillium sp. isolated from Centella asiatica. Curr Res Environ Appl Mycol 4 (1): 34-43. DOI: 10.5943/ream/4/1/3.

Floudas D, Hibbett DS. 2015. Revisiting the taxonomy of Phanerochaete (Polyporales, Basidiomycota) using a four-gene dataset and extensive ITS sampling. Fungal Biol 119: 679-719. DOI: 10.1016/j.funbio.2015.04.003

Ginting RCBB, Sukarno N, Widyastuti U, Darusman LK, Kanaya S. 2013. Diversity of endophytic fungi from red ginger (Zingiber officinale Rosc.) plant and their inhibitory effect to Fusarium oxysporum plant pathogenic fungi. Hayati J Biosci 20 (3): 127-137. 10.4308/hjb.20.3.127

Glienke C, Pereira OL, Stringari D, Fabris J, Cunnington J, Shivas RG, Crous PW. 2011. Endophytic and pathogenic Phyllosticta species, with reference to those associated with citrus black spot. Persoonia 26: 47-56. DOI: 10.3767/003158511X569169.

Gomes RR, Glienke1 C, Videira SIR, Lombard L, Groenewald JZ, Crous PW. 2013. Diaporthe: a genus of endophytic, saprobic and plant pathogenic fungi. Persoonia 31: 1-41

Gónzalez D, Rodriguez M, Boekhout T, Stalpers J, Kuramae EE, Nakatanie AK, Vilgalys R, Cubetab MA. 2016. Phylogenetic relationships of Rhizoctonia fungi within the Cantharellales. Fungal Biol 120 (4): 603-619. DOI: 10.1016/j.funbio.2016.01.012.

Gupta AK. 2013. Centella asiatica. The IUCN Red List of Threatened Species 2013: e.T168725A19645149. DOI: 10.2305/IUCN.UK.2013-1.RLTS.T168725A19645149.en.

Gupta S, Chaturvedi P. 2017. Foliar endophytic diversity of Centella asiatica ( L .) urban in relation to different seasons and leaf age. Intl $\mathbf{J}$ Curr Microbiol Appl Sci 6 (6): 468-477. DOI: doi.org/10.20546/ijcmas.2017.606.054.

Hasyyati NS, Suprihadi A, Raharjo B, Dwiatmi K. 2017. Isolasi dan karakterisasi kapang endofit dari Pegagan (Centella asiatica (L.) URBAN). Jurnal Biologi 6 (2): 66-74. [Indonesian]

Herron DA, Wingfield MJ, Wingfield BD, Rodas CA, Marincowitz S, Steenkamp ET. 2015. Novel taxa in the Fusarium fujikuroi species complex from Pinus spp. Stud Mycol 80: 131-150

Hidayat I, Radiastuti N, Rahayu G, Achmadi S, Okane I. 2016. Three quinine and cinchonidine producing Fusarium species from Indonesia. Curr Res Environ Appl Mycol 6 (1): 20-34. DOI: $10.5943 /$ cream/5/4/4.

Huang W, Cai YZ, Surveswaran S, Hyde KD, Corke H, Sun M. 2009. Molecular phylogenetic identification of endophytic fungi isolated from three Artemisia species. Fungal Div 36: 69-88.

Hyde KD, Soytong K. 2008. The fungal endophyte dilemma. Fungal Div 33: $163-173$.

Jayasiri SC, Hyde KD, Jones EBG, McKenzie EHC, Jeewon R, Phillips AJL, Bhat DJ, Wanasinghe DN, Liu JK, Lu YZ, Kang JC, Xu J, Karunarathna SC. 2019. Diversity, morphology and molecular phylogeny of Dothideomycetes on decaying wild seed pods and fruits. Mycosphere 10 (1): 1-186. Doi 10.5943/mycosphere/10/1/1

Jia M, Chen L, Xin HL, Zheng CJ, Rahman K, Han T, Qin LP. 2016. A Friendly relationship between endophytic fungi and medicinal plants: A Systematic Review. Front Microbiol 7 (906): 1-14. DOI: 10.3389/fmicb.2016.00906.

Jin HQ, Liu HB, Xie YY, Zhang YG, Xu QQ, Mao LJ, Zhang CL. 2017. Effect of the dark septate endophytic fungus Acrocalymma vagum on heavy metal Content in Tobacco Leaves. Symbiosis 74 (2): 89-95. DOI: $10.1007 / \mathrm{s} 13199-017-0485-4$.

Joshi K, Chaturvedi P. 2013. Therapeutic efficiency of Centella asiatica (L.) Urb. an underutilized green leafy vegetable: an overview. Intl J Pharma Bio Sci (4)1: 135-149.

Jurjevic Z, Peterson SW, Horn BW. 2012. Aspergillus section Versicolores: nine new species and multilocus DNA sequence based phylogeny. IMA Fungus 3 (1): 59-79. DOI: 10.5598/imafungus.2012.03.01.07.

Justo A, Hibbett DS. 2011.Phylogenetic classification of Trametes (Basidiomycota, Polyporales) based on a five-marker dataset. Taxon 60 (6): 1567-1583. DOI: 10.1002/tax.606003

Kaur A, Rogers KD, Swenson DE, Dowd PF, Wicklow DT, Gloer JB. 2014. Bioactive natural products from fungicolous Hawaiian isolates : secondary metabolites from a Phialemoniopsis. Mycology 5 (3): 120129. DOI: 10.1080/21501203.2014.931309.

Kauserud H, Schumacher T.2003. Ribosomal DNA variation, recombination and inheritance in the basidiomycete Trichaptum abietinum: implications for reticulate evolution. Heredity 91 (2): 163-172. 
Kongprapan T, Rukachaisirikul V, Saithong S, Phongpaichit S, Poonsuwan W, Sakayaroj J. 2015. Cytotoxic cytochalasins from the endophytic fungus Eutypella scoparia PSU-H267. Phytochem Lett 13 (2015): 171-176.

Nalini MS, Sunayana N, Prakash HS. 2014. Endophytic fungal diversity in medicinal plants of Western Ghats, India. Intl J Biodiv 2014: 1-9.

Mayorquin JS, Wang DH, Twizeyimana M, Eskalen. 2016. Identification, distribution, and pathogenicity of Diatrypaceae and Botryosphaeriaceae associated with Citrus Branch Cankerin the Southern California Desert. Fungal Dis 100 (12): 2402-2413. DOI: 10.1094/PDIS-03-16-0362

Perdomo H, Garcia D, Gené J, Cano J, Sutton DA, Summerbell R, Guarro J. 2013. Phialemoniopsis, a new genus of Sordariomycetes, and new species of Phialemonium and Lecythophora. Mycologia 105 (2): 398 421. DOI: $10.3852 / 12-137$

Prihastuti H, Cai L, Chen HI, McKenzie EH, Hyde KD. 2009. Characterization of Colletotrichum species associated with coffee berries in northern Thailand. Fungal Div 39: 89-109

Radiastuti N. 2015. Diversity of Culturable Endophytic Fungi in Cinchona Calisaya Wedd.: Molecular Phylogeny and Alkaloid Profile. [Disertation] Bogor Agriculture University, Bogor. [Indonesian]

Radiastuti N, Rahayu G, Okane I, Hidayat I, Achmadi SS. 2015. Alkaloid profile of endophytic Diaporthe spp. from Cinchona calisaya. Jurnal Penelitian Teh dan Kina 18 (1): 87-99. [Indonesian]

Radji M, Kurniati M, Kiranasari A. 2015. Comparative antimycobacteria activity of some Indonesian medicinal plants against multi-drug resistant Mycobacterium tuberculosis. J Appl Pharmaceut Sci 5 (1): 019-022. DOI: $10.7324 / J A P S .2015 .50104$

Rakotoniriana EF, Munaut F, Decock C, Randriamampionona D, Andriambololoniaina M, Rakotomalala T, Corbisier AM. 2008 Endophytic fungi from leaves of Centella asiatica: occurrence and potential interactions within leaves. Antonie van Leeuwenhoek Intl J General Mol Microbiol 93 (1-2): 27-36. DOI: 10.1007/s10482-0079176-0.

Rai MK, Tiwari VV, Irinyi L, Ko“vics GJ. 2014. Advances in taxonomy of Genus Phoma: Polyphyletic nature and role of phenotypic traits and molecular systematics. Indian J Microbiol 54 (2): 123-128 DOI 10.1007/s12088-013-0442-8

Su YY, Cai, L. 2012. Polyphasic characterisation of three new Phyllosticta spp. Persoonia 28: 76-84. DOI: 10.3767/003158512X645334

Su L, Niu YC. 2018. Multilocus phylogenetic analysis of Talaromyces species isolated from cucurbit plants in China and description of two new species, T. cucurbitiradicus and T. endophyticus. Mycologia 110 (2): 375-386, DOI: 10.1080/00275514.2018.1432221

Swofford DL. 2002. Phylogenetic analysis using parsimony (and Other Methods). Version 4. Sinauer Associates. Sunderland, MA

Wang Y, Xu L, Ren W, Zhao D, Zhu Y, Wu X. 2012. Bioactive metabolites from Chaetomium globosum L18, an endophytic fungus in the medicinal plant Curcuma wenyujin. Phytomedicine 19: 364368. DOI: 10.1016/j.phymed.2011.10.011.

Wang XC, Chen K, Zeng ZQ, Zhuang WY. 2017. Phylogeny and morphological analyses of Penicillium section Sclerotiora (Fungi) lead to the discovery of five new species. Sci Rep 7: 8233. DOI: 10.1038/s41598-017-08697-1

Watanabe M, Yonezawa T, Lee K, Kumagai S, Konishi YS, Goto K, Kudo YH. 2011. Molecular phylogeny of the higher and lower taxonomy of the Fusarium genus and differences in the evolutionary histories of multiple genes. Evol Biol 11: 322-338. DOI: 10.1186/1471-2148-11-322

Wu LS, Hu CL, Han T, Zheng CJ, Ma XQ, Rahman K, Qin LP. 2012. Cytotoxic metabolites from Perenniporia tephropora, an endophytic fungus from Taxus chinensis var. mairei. Appl Microbiol Biotechnol 97: $305-315$

Zahara K, Bibi Y, Tabassum S. 2014. Clinical and therapeutic benefits of Centella asiatica. Pure Appl Biol 3 (4): 152-159. DOI: 10.19045/bspab.2014.34004

Zhao C, Cui B. 2017. Morphological and molecular identification of four new resupinate species of Perenniporia (Polyporales) from southern China. Mycologia 105 (4): 945-958. DOI: 10.3852/12-201 